\title{
Collagen Alpha-1(XVIII) Chain
}

National Cancer Institute

\section{Source}

National Cancer Institute. Collagen Alpha-1(XVIII) Chain. NCI Thesaurus. Code C17792.

Collagen alpha-1(XVIII) chain (1754 aa, $178 \mathrm{kDa}$ ) is encoded by the human COL18A1

gene. This protein is involved in extracellular matrix structure, closure of the neural tube and retinal development. 